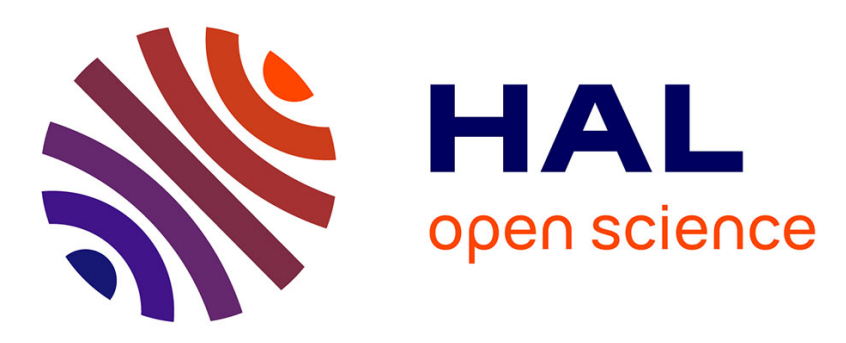

\title{
DNA adduct formation and 7-ethoxyresorufin o-deethylase induction in primary culture of rainbow trout hepatocytes exposed to benzo(a)pyrene
}

J.F. Masfaraud, Alain Devaux, A. Pfohl-Leszkowicz, C. Malaveille, Gilles Monod

\section{To cite this version:}

J.F. Masfaraud, Alain Devaux, A. Pfohl-Leszkowicz, C. Malaveille, Gilles Monod. DNA adduct formation and 7-ethoxyresorufin o-deethylase induction in primary culture of rainbow trout hepatocytes exposed to benzo(a)pyrene. Toxicology in Vitro, 1992, 6 (6), pp.523-531. 10.1016/0887-2333(92)90064X . hal-02715678

\section{HAL Id: hal-02715678 \\ https://hal.inrae.fr/hal-02715678}

Submitted on 1 Jun 2020

HAL is a multi-disciplinary open access archive for the deposit and dissemination of scientific research documents, whether they are published or not. The documents may come from teaching and research institutions in France or abroad, or from public or private research centers.
L'archive ouverte pluridisciplinaire HAL, est destinée au dépôt et à la diffusion de documents scientifiques de niveau recherche, publiés ou non, émanant des établissements d'enseignement et de recherche français ou étrangers, des laboratoires publics ou privés. 


\title{
DNA ADDUCT FORMATION AND 7-ETHOXYRESORUFIN $O$-DEETHYLASE INDUCTION IN PRIMARY CULTURE OF RAINBOW TROUT HEPATOCYTES EXPOSED TO BENZO $[a]$ PYRENE
}

\author{
J.-F. Masfaraud*, A. Devaux*, A. Pfohl-Leszkowicz $\dagger$, C. Malaveille $\ddagger$ and G. Monod* \\ *Laboratoire d'Ecotoxicologie, Institut National de la Recherche Agronomique, Ecole Vétérinaire de \\ Lyon, BP 83, 69280 Marcy l'Etoile, †Laboratoire de Biochimie, Institut de Biologie Moléculaire et \\ Cellulaire du Centre National de la Recherche Scientifique et Université Louis Pasteur, 15 rue Descartes, \\ 67084 Strasbourg and ‡International Agency for Research on Cancer, 150 cours A. Thomas, \\ 69008 Lyon, France
}

(Received 14 February 1992)

\begin{abstract}
The formation of DNA adducts, using the ${ }^{32} \mathrm{P}$-postlabelling assay, and induction of 7-ethoxyresorufin $O$-deethylase (EROD) were investigated in a primary culture of rainbow trout hepatocytes exposed to benzo[a]pyrene $(\mathrm{B}[a] \mathrm{P})$. Concentrations of 0.1 and $1 \mu \mathrm{M}-\mathrm{B}[a] \mathrm{P}$ were shown to induce EROD whereas $10 \mu \mathrm{M}$ was an inhibitory concentration. DNA adducts were detected for $12 \mathrm{hr}$ to $72 \mathrm{hr}$ after exposure to $1 \mu \mathrm{M}-\mathrm{B}[a] \mathrm{P}$ whereas EROD activity was increased $36 \mathrm{hr}$ after treatment. The pattern of adducts was shown to be identical to that obtained after $\mathrm{B}[a] \mathrm{P}$ treatment of rainbow trout in vivo, as demonstrated by co-chromatography of the adducts. Pre-exposure of hepatocytes for $48 \mathrm{hr}$ to $\beta$-naphthoflavone $(\beta \mathrm{NF})$ and subsequent $24-\mathrm{hr}$ exposure to $1 \mu \mathrm{M}-\mathrm{B}[a] \mathrm{P}$ did not lead to increased DNA adduct formation although $\beta$ NF treatment led to a 3.4-fold induction of EROD activity at the time of $\mathrm{B}[a] \mathrm{P}$ addition. This study suggests that primary culture of rainbow trout hepatocytes provides a suitable method for studying DNA adduct formation and its modulating factors in vitro.
\end{abstract}

\section{INTRODUCTION}

Exposure of living organisms to xenobiotics leads to interactions between those chemicals and biological systems that may give rise to biochemical disturbances or/and adaptive responses (e.g. enzyme induction). Biochemical events resulting from exposure to xenobiotics have been proposed as biomarkers, generally seen as "changes in a biological system that can be related to an exposure to, or effect from, a specific xenobiotic or type of toxic material' (Henderson et al., 1989).

Among molecular targets of xenobiotics, interest has been focused on DNA, since DNA-xenobiotic binding is considered to be a critical step that may initiate mutagenesis and carcinogenesis (Miller and Miller, 1981). Xenobiotics may interact with DNA either directly or after transformation by metabolizing enzymes into reactive species that react with DNA forming DNA addition products (DNA adducts). Thus, DNA adducts were proposed as a biomarker of exposure to genotoxic compounds (Henderson et al., 1989; Perera, 1987).

Abbreviations: $\mathrm{AHH}=$ aryl hydrocarbon hydroxylase; $\mathbf{B}[a] \mathbf{P}=$ benzo $[a]$ pyrene; $\quad \beta \mathrm{NF}=\beta$-naphthoflavone; $\mathrm{BPDE}=\mathrm{B}[a] \mathrm{P}$ 7,8-diol 9,10-epoxide; $\mathrm{DMSO}=\mathrm{di}$ methyl sulphoxide; EROD $=7$-ethoxyresorufin $O$-deethylase; $P-450=$ cytochrome $P-450 ; \quad P A H=$ polycyclic aromatic hydrocarbon; $\mathrm{PEI}=$ polyethyleneimine.
Polycyclic aromatic hydrocarbons (PAHs) are widespread carcinogenic micropollutants that form DNA adducts after activation by cytochrome $P-450$ (P-450) enzymes (Conney, 1982; IARC, 1987), which are present in most living organisms, including fish. A main $P-450$ responsible for $\mathrm{PAH}$ activation in rodents has been characterized as a member of the $P 4501$ A subfamily, namely $P 4501$ Al (Ioannides and Parke, 1990). A fish $P-450$ implicated in PAH metabolism and activation is very similar to the rodent $P 4501$ Al form, particularly in its induction by planar compounds enhancing the metabolic activation of PAHs (Goksøyr et al., 1991; Stegeman and Lech, 1991). The $P-450$ inducible by planar xenobiotics in fish has been proposed as a biomarker of exposure to planar micropollutants (Stegeman and Lech, 1991).

Cells isolated from mammalian and fish tissues can be used in various cytotoxicity and genotoxicity assays as alternatives to experiments in vivo to reduce the use of animals and to lessen the cost/time of testing (Babich and Borenfreund, 1991). Cultured fish cells have been shown to metabolize and activate PAHs into DNA-damaging species (Smolarek et al., 1987).

Recently, the inducibility of P4501A based on 7-ethoxyresorufin $O$-deethylase (EROD) activity was evaluated in primary culture of rainbow trout hepatocytes (Pesonen and Andersson, 1991; Vaillant et al., 1989). Furthermore, the pattern of P4501A 
induction (rate, time trend) in this cell system appeared to be very similar to that in fish liver after exposure to PAHs (A. Devaux, unpublished data).

The objective of the present study was to examine whether DNA adduction is associated with P4501A enzymatic activity in trout hepatocytes exposed to the model PAH benzo $[a]$ pyrene $(\mathrm{B}[a] \mathrm{P})$ with or without pre-exposure to the well known inducer of $P 4501 \mathrm{~A}$, $\beta$-naphthoflavone ( $\beta \mathrm{NF})$. To examine the biological relevance of our system in vitro, we also compared the pattern of hepatic $\mathrm{B}[a] \mathrm{P}-\mathrm{DNA}$ adduction in vivo and in vitro.

\section{MATERIALS AND METHODS}

Animals. Rainbow trout (Oncorhynchus mykiss) with an average body weight of $250 \mathrm{~g}$, were obtained from a local hatchery (Font-Rome, France). Trout were kept in tanks with aerated, charcoal-filtered tap water at a temperature of $10^{\circ} \mathrm{C}$ and fed with commercial pellets. Fish were acclimatized to laboratory conditions for a minimum of one month before experiments started.

Chemicals. Medium 199, antibiotic-antimycotic solution $(10,000 \mathrm{U}$ penicillin $\mathrm{G} / \mathrm{ml}, 10 \mathrm{mg}$ streptomycin $/ \mathrm{ml}, 25 \mu \mathrm{g}$ amphotericin $\mathrm{B} / \mathrm{ml}$, in $0.9 \% \mathrm{NaCl}$ ), L-glutamine and collagenase type IV were from Sigma Chemicals (St Quentin, Fallavier, France). $\beta N F$ was purchased from Aldrich (St Quentin, Fallavier, France) and 7-ethoxyresorufin from Boehringer-Mannheim (Meylan, France). Proteinase $K$, and RNases $A$ and $T_{1}$ used for DNA isolation were from Sigma Chemicals and $\alpha$-amylase was from Boehringer-Mannheim. Enzymes used for DNA adduct analysis were from Worthington Biochemical Corp. (Freehold, NJ, USA) (micrococcal nuclease, spleen phosphodiesterase), Boehringer-Mannhein (Penicillium citrinum nuclease $\mathrm{P}_{1}$ ), US Biochemical Corp. (Cleveland, OH, USA) (polynucleotide kinase $\mathrm{T}_{4}$ ) and Sigma Chemicals (potato apyrase). $[\gamma-$ ${ }^{32}$ P]ATP (sp. act. $3000 \mathrm{Ci} / \mathrm{mmol}$ ) was supplied by Amersham (Bucks., UK). All other reagents were of analytical grade.

Isolation of hepatocytes and culture conditions. Rainbow trout hepatocytes were isolated by a modification of the two-step perfusion method (Seglen, 1972). Fish were killed by a blow on the head and a ventral incision was made from the pelvic fins to the gills. The portal vein was cannulated and the liver perfused at room temperature (approx. $20^{\circ} \mathrm{C}$ ) using a peristaltic pump at a flow rate of $11 \mathrm{ml} / \mathrm{min}$. The first $\mathrm{Ca}^{2+}$-free perfusion buffer $[9.4 \mathrm{~g} \mathrm{NaCl} /$ litre, $0.235 \mathrm{~g}$ $\mathrm{KCl} /$ litre, $\quad 0.117 \mathrm{~g} \quad \mathrm{Na}_{2} \mathrm{HPO}_{4} \cdot 12 \mathrm{H}_{2} \mathrm{O} /$ litre, $\quad 2.8 \mathrm{~g}$ HEPES/litre, pH 7.4, 300 mosmol] was pumped from a reservoir to a bubble trap. After 20 min perfusion, the liver was perfused for $20 \mathrm{~min}$ with the second buffer containing $60 \mathrm{mg}$ collagenase $(8 \mathrm{~g} \mathrm{NaCl} /$ litre, $0.2 \mathrm{~g} \mathrm{KCl} /$ litre, $0.1 \mathrm{~g} \mathrm{Na}_{2} \mathrm{HPO}_{4} \cdot 12 \mathrm{H}_{2} \mathrm{O} /$ litre, $2.38 \mathrm{~g} \mathrm{HEPES} / \mathrm{litre}, 0.74 \mathrm{~g} \mathrm{CaCl} /$ /litre, $\mathrm{pH}$ 7.4,
300 mosmol). Cell dispersion was achieved by gently raking with a spatula. After filtration through a cotton gauze and a nylon mesh, cells were centrifuged for $2 \mathrm{~min}$ at $80 \mathrm{~g}$ and washed twice with culture medium (medium 199, $10 \mathrm{ml}$ antibiotic-antimycotic solution, $2 \mathrm{mM}$-L-glutamine, $1 \mathrm{~g} \mathrm{HEPES} /$ litre, $0.35 \mathrm{~g}$ $\mathrm{NaHCO}_{3} /$ litre, $1.6 \mathrm{~g} \mathrm{Na}_{2} \mathrm{HPO}_{4} \cdot 12 \mathrm{H}_{2} \mathrm{O} /$ litre, $0.14 \mathrm{~g}$ $\mathrm{CaCl}_{2} /$ litre, pH 7.4, 300 mosmol). Cell viability was assessed by a dye exclusion test using $0.4 \%$ trypan blue. Each perfusion yielded about $0.5-1 \times 10^{9}$ hepatocytes, with viability over $90 \%$. All liquids and glassware were sterilized before use by filtration or autoclaving. After cells had been counted using a Neubauer chamber, hepatocytes in culture medium were seeded at a density of $2 \times 10^{6}$ cells $/ \mathrm{ml}$ on to surface-treated plastic petri dishes (Falcon Primaria) and incubated at $12^{\circ} \mathrm{C}$.

Enzyme and protein assays. Cells were lysed in $0.15 \mathrm{M}-\mathrm{KCl}, 50 \mathrm{~mm}$-phosphate buffer, $\mathrm{pH} 8.0$, using a Potter-Elvehjem homogenizer. EROD activity was measured at $20^{\circ} \mathrm{C}$ as previously described (Monod et al., 1987) using a 7-ethoxyresorufin final concentration of $5 \mu \mathrm{M}$ in a $50 \mathrm{~mm}$-phosphate buffer, $\mathrm{pH} 8.0$. Protein concentration was determined according to Hartree (1972) with bovine serum albumin as a standard.

DNA adduct analysis. Hepatocytes were harvested by flushing the petri dishes with culture medium. Cell suspensions were then centrifuged $(3 \mathrm{~min}, 100 \mathrm{~g}$ ) and pellets were resuspended in $1 \mathrm{ml}$ of a $0.1 \mathrm{M}-\mathrm{Tris}-\mathrm{HCl}$ buffer, $\mathrm{pH} 7.4$, and frozen at $-80^{\circ} \mathrm{C}$ until use. DNA was isolated from hepatocytes according to a procedure involving proteinase $\mathrm{K}$ digestion, RNAse and $\alpha$-amylase digestion, phenol/chloroform extraction and ethoxyethanol precipitation (Dunn et al., 1987). The precipitated DNA was recovered in distilled water and the amount of extracted DNA was determined spectrophotometrically assuming $1 A_{260}=50 \mu \mathrm{g} \mathrm{DNA} / \mathrm{ml}$. Purity of samples was estimated by the $A_{260} / A_{280}$ ratio, which was found to be between 1.6 and 1.8 .

DNA was analysed for $\mathrm{B}[a] \mathrm{P}$ adducts using the postlabelling assay (Randerath et al., 1981) (nuclease $\mathbf{P}_{1}$-mediated enrichment version; Reddy and Randerath, 1986). $20 \mu \mathrm{g}$ hepatocyte DNA were first hydrolysed to 3'-nucleoside monophosphates by treatment with micrococcal endonuclease and spleen phosphodiesterase. The digest was then treated with nuclease $P_{1}$ that dephosphorylated only nonadducted $3^{\prime}$-nucleoside monophosphates to nucleosides. The adducted 3'-nucleoside monophosphates were subsequently labelled by polynucleotide $T_{4}$ kinase-catalysed transfer of ${ }^{32} \mathrm{P}$ from $\left[\gamma-{ }^{32} \mathrm{P}\right] \mathrm{ATP}$, whereas nucleosides were not substrates for the enzyme. Finally, the ${ }^{32}$ P-labelled nucleoside biphosphates were purified and separated by anion exchange thin-layer chromatography on polyethyleneimine (PEI)-cellulose plates eluted in several directions, as follows (Lu et al., 1986). Inorganic phosphate and labelled impurities were removed by application of 
the labelled digest to the origin of a PEI-cellulose plate, which was eluted overnight with an aqueous electrolyte $\left(\mathrm{D} 1=2.3 \mathrm{M}-\mathrm{NaH}_{2} \mathrm{PO}_{4}, \mathrm{pH}\right.$ 5.7). The purified ${ }^{32} \mathrm{P}$-labelled adducts were then contact-transferred to a new PEI-cellulose plate and separated by bidimensional elution (D2 $=7.7 \mathrm{M}$-urea $/ 4.8 \mathrm{M}$-lithium formate, $\mathrm{pH} 3.5$; D3 $=9.3 \mathrm{M}$-urea $/ 1.6 \mathrm{M}-\mathrm{LiCl} / 0.5 \mathrm{M}$ Tris, $\mathrm{pH}$ 8). A final elution $\left(\mathrm{D} 4=1.7 \mathrm{M}-\mathrm{NaH}_{2} \mathrm{PO}_{4}\right.$, $\mathrm{pH}$ 6) was carried out in order to reduce the background radioactivity of plates.

DNA adducts appeared as black spots on the autoradiographies of the PEI-cellulose plates. The radioactive PEI-cellulose material corresponding to the spots was scraped from the plate and measured by Cerenkov counting. Blank areas were also removed in order to subtract background radioactivity from each count. Quantification of DNA adducts was based on the spectrophotometric measurement of DNA, the radioactivity of the spots and the specific activity of $\left[\gamma-{ }^{32}\right.$ P]ATP.

Co-chromatography experiments were carried out using liver DNA from immature rainbow trout treated ip with $80 \mathrm{mg} \mathrm{B}[a] \mathrm{P} / \mathrm{kg}$ body weight (Masfaraud et al., 1992).

Statistics. Statistical analyses were performed by the Mann-Whitney $U$-test (Siegel, 1956).

Experimental procedure. $\beta \mathrm{NF}$ and $\mathrm{B}[a] \mathrm{P}$ were dissolved in dimethyl sulphoxide (DMSO) and mixed with the culture medium to the appropriate concentrations (the final concentration of DMSO was $0.1 \%$ which was shown to be non-cytotoxic). In each experiment the control received DMSO alone.

In experiment I, B[a]P in DMSO $(0.01,0.1,1$ and $10 \mu \mathrm{M}-\mathrm{B}[a] \mathrm{P}$ final concentration in assays) was added to the culture medium $24 \mathrm{hr}$ after cell seeding and EROD activity was measured 48 and $72 \mathrm{hr}$ after exposure.

In experiment $\mathrm{II}, \mathrm{B}[a] \mathrm{P}(1 \mu \mathrm{M}$ final concentration in assays) was added $24 \mathrm{hr}$ after cell seeding and measurements of the DNA adducts as well as EROD activity were made $12,24,36$ and $72 \mathrm{hr}$ after $\mathrm{B}[a] \mathrm{P}$ exposure.

In experiment III, the DNA adduct level and EROD activity were measured in hepatocytes exposed to $\mathrm{B}[a] \mathrm{P}$ that had, or had not, received $\beta \mathrm{NF}$ pretreatment (Fig. 1).

\section{RESULTS}

Effect of B[a]P treatment of hepatocytes on EROD activity (experiment I)

The effect of $\mathrm{B}[a] \mathrm{P}$ treatment after 48 or $72 \mathrm{hr}$ was studied at four different concentrations $(0.01,0.1,1$ and $10 \mu \mathrm{M}-\mathrm{B}[a] \mathrm{P}$ final concentration in assays). Table 1 shows a dose-dependent induction of EROD following treatment with $\mathrm{B}[a] \mathrm{P}$ in the range 0.01 to $1 \mu \mathrm{M}$; inhibition was observed for $10 \mu \mathrm{M}-\mathrm{B}[a] \mathrm{P}$.

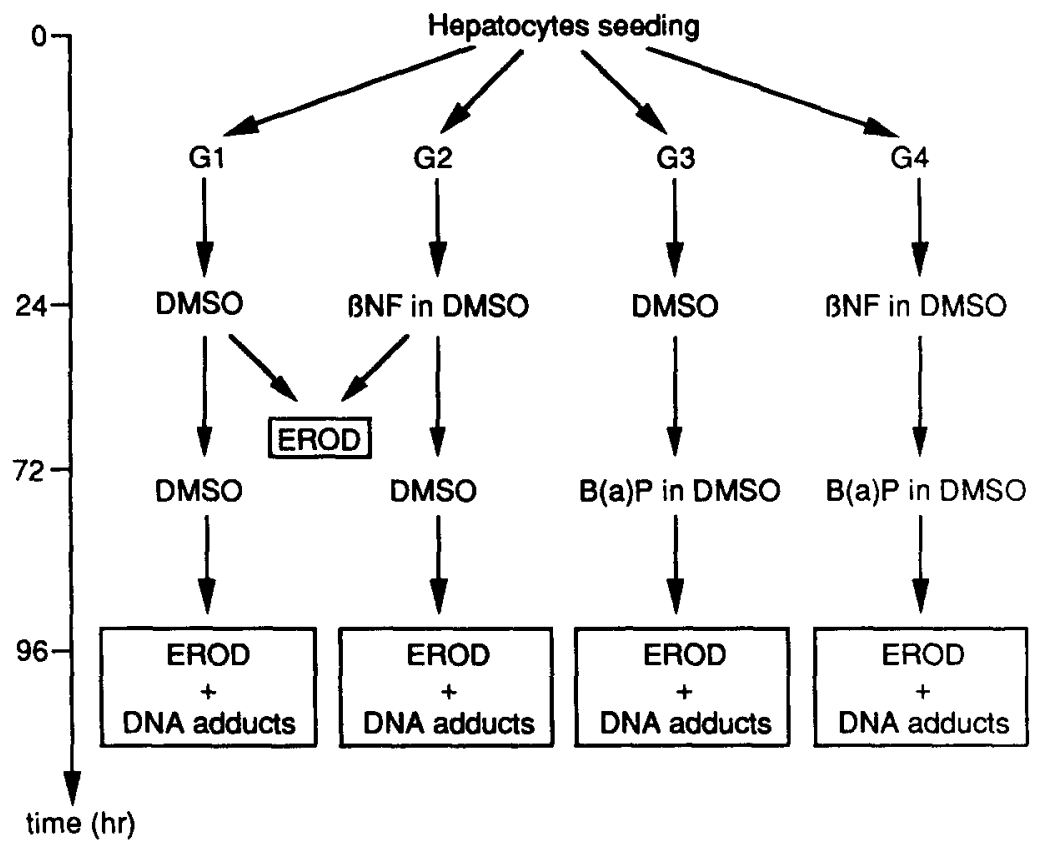

Fig. 1. Protocol of hepatocytes treatment before measurement of activity of 7-ethoxyresorufin $O$ deethylase (EROD) activity and level of DNA adducts. Dishes containing hepatocytes were divided, after seeding, into four groups: G1, G2, G3 and G4. After $24 \mathrm{hr}$ culture, G1 and G3 received DMSO alone while G2 and G4 received $0.36 \mu \mathrm{M}-\beta$ NF (final concentration), which previously had been shown to be the optimum concentration for induction (data not shown). After $72 \mathrm{hr}$ culture, EROD activity was measured in some G1 and G2 dishes; DMSO was added to the remaining G1 and G2 dishes; G3 and G4 received $1 \mu \mathrm{M}-\mathrm{B}[a] \mathrm{P}$ (final concentration). After $96 \mathrm{hr}$ culture (24 hr after the addition of $\mathrm{B}[a] \mathrm{P})$ EROD activity and DNA adduct level were assessed in G1, G2, G3 and G4. 
Table 1 . EROD activity ( $\mathrm{pmol} \cdot \mathrm{min}^{-1} \cdot \mathrm{mg} \mathrm{protein}^{-1}$ ) as a function of benzo $[a]$ pyrene $(\mathrm{B}[a] \mathrm{P})$ concentration in assays measured after 48 and $72 \mathrm{hr}$ exposure to $\mathrm{B}[\mathrm{a}] \mathrm{P}$

\begin{tabular}{|c|c|c|c|c|}
\hline \multirow{2}{*}{$\begin{array}{c}\text { Time after } \\
\text { B }[a] \mathbf{P} \text { addition } \\
\text { (hr) }\end{array}$} & \multicolumn{4}{|c|}{$\begin{array}{l}\text { EROD activity after exposure to various } \\
\text { concentrations }(\mu \mathrm{M}) \text { of } \mathrm{B}[a] \mathrm{P} \dagger\end{array}$} \\
\hline & Control & 0.01 & 0.1 & 10 \\
\hline $\begin{array}{l}48 \\
72\end{array}$ & $\begin{array}{l}80 \pm 2 \\
71 \pm 3\end{array}$ & $\begin{array}{l}108 \pm 1^{*} \\
101 \pm 3^{*}\end{array}$ & $\begin{array}{l}128 \pm 4^{*} 159 \pm 13^{*} \\
122 \pm 6^{*} 142 \pm 6^{*}\end{array}$ & $\begin{array}{l}63 \pm 6^{*} \\
57 \pm 2^{*}\end{array}$ \\
\hline \multicolumn{5}{|c|}{$\begin{array}{l}\text { EROD }=7 \text {-ethoxyresorufin } O \text {-deethylase } \\
\text { added to the culture medium } 24 \mathrm{hr} \text { after cell seeding. } \\
\text { alue corresponds to mean value } \pm \mathrm{SD} \text { from three dishes. } \\
\text { ks indicate significant differences from the control } \\
.05 \text { ). }\end{array}$} \\
\hline
\end{tabular}

Consequently, $1 \mu \mathrm{M}-\mathrm{B}[a] \mathrm{P}$ was chosen for the subsequent experiments.

$D N A$ adducts in hepatocytes treated up to $72 \mathrm{hr}$ with $1 \mu \mathrm{M}-\mathrm{B}[\mathrm{a}] P$ (experiment $I I$ ); comparison with adduction in liver in vivo

DNA adducts were assessed 12, 24, 36 and $72 \mathrm{hr}$ after $\mathrm{B}[a] \mathrm{P}$ treatment. Adducts were detected without change in the chromatographic pattern at each sampling time in $\mathrm{B}[a] \mathrm{P}$-treated hepatocytes and were absent from DMSO-treated hepatocytes. Plate 1 shows the pattern of DNA adducts from 24-hr B $[a]$ Ptreated hepatocytes, which was shown to be identical to that observed after treatment in vivo, as demonstrated by the co-chromatography experiment involving adducted nucleotides from $\mathrm{B}[a] \mathrm{P}$-treated hepatocytes and from the liver of $\mathrm{B}[a] \mathrm{P}$-treated rainbow trout.

Table 2 gives confirmation of the identity of adducts resulting from $\mathrm{B}[a] \mathrm{P}$ treatment of hepatocytes and trout, as demonstrated by additivity of the radioactivity of each spot when counting the corresponding spot revealed by co-chromatography. Nevertheless, the relative contribution of the spots was not the same in hepatocytes and in trout liver.

During this experiment, EROD activity measured 12,36 and $72 \mathrm{hr}$ after $\mathrm{B}[a] \mathrm{P}$ treatment was induced $0.9-, 1.2-$ and 1.9-fold, respectively, induction being statistically significant at 36 and $72 \mathrm{hr}$ (data not shown).

Effect of $\beta N F$ pretreatment of hepatocytes on the formation of $B[a] P-D N A$ adducts (experiment III)

Plate 2 shows that no adduct was detectable in control and $\beta$ NF-treated hepatocytes $(0.36 \mu \mathrm{M}$ final concentration in assays) and that pre-exposure to $\beta \mathrm{NF}$ for $48 \mathrm{hr}$ did not modify the DNA adduct pattern observed following a subsequent 24-hr exposure to $1 \mu \mathrm{M}-\mathrm{B}[a] \mathrm{P}$ when compared with hepatocytes treated with $\mathbf{B}[a] \mathrm{P}$ alone. Moreover, preexposure to $\beta \mathrm{NF}$ inhibited DNA adduct formation without modifying the relative contribution of the spots (Table 3). Nevertheless, Table 4 shows that, at the time of addition of $\mathrm{B}[a] \mathrm{P}$ to the culture medium, EROD activity was significantly induced by $\beta \mathrm{NF}$ (3.4-fold). Moreover, $24 \mathrm{hr}$ after the addition of $\mathrm{B}[a] \mathrm{P}$, the EROD activity induced was always significantly (2-fold) higher in hepatocytes pre-exposed to $\beta \mathrm{NF}$ than in those pre-exposed to DMSO, while $\mathrm{B}[a] \mathrm{P}$ alone significantly induced EROD activity.

\section{DISCUSSION}

This study confirms the inducibility of P4501Adependent enzyme activity in a primary culture of rainbow trout hepatocytes and demonstrates the ability of cultured cells to metabolize $\mathrm{B}[a] \mathrm{P}$ into DNAdamaging species in the same way as occurs in vivo; the results also suggest that DNA adduct formation cannot be related simply to the EROD activity level.

The induction of EROD by $\mathrm{B}[a] \mathrm{P}$ in a primary culture of rainbow trout hepatocytes is similar to that found previously with $\beta \mathrm{NF}$ and dioxin as inducers (Pesonen and Andersson, 1991; Vaillant et al., 1989), and parallels the induction of aryl hydrocarbon hydroxylase (AHH; a P4501A-dependent activity using $\mathrm{B}[a] \mathrm{P}$ as a substrate) observed with $\mathrm{B}[a] \mathrm{P}$ and other PAH-like compounds in cultured mammalian hepatocytes (Nemoto et al., 1990). In a recent study conducted in rainbow trout from the same fish farm, ip treatment ( $80 \mathrm{mg} \mathrm{B}[\mathrm{a}] \mathrm{P} / \mathrm{kg}$ body weight) led to a 2- to 3-fold induction of microsomal hepatic EROD activity (Masfaraud et al., 1992). This, and the present study, indicate that similar responses are obtained in cultured hepatocytes and in vivo. The fact that EROD induction depends on the penetration of the inducer into the cell (Okey, 1990) supports the assumption that exposure of hepatocytes to $\mathrm{B}[a] \mathrm{P}$ caused subsequent penetration of this PAH into the cells.

The study demonstrates the inhibitory effect on EROD activity of $10 \mu \mathrm{M}-\mathrm{B}[a] \mathrm{P}$ in the culture medium. This result suggests that this concentration of $\mathrm{B}[a] \mathrm{P}$ causes cell disturbances rather than competititive occupation of the active site of P4501A by $\mathbf{B}[a] \mathrm{P}$, because similar inhibition was observed when AHH was measured (data not shown). This observation underlines the importance of selecting a xenobiotic concentration in cellular systems when several parameters have to be investigated, and justifies the choice of $1 \mu \mathrm{M}-\mathrm{B}[a] \mathrm{P}$ for further experiments to study the relationship between EROD induction and the concentration of DNA adducts.

The ability of fish species to metabolize PAHs, especially $\mathrm{B}[a] \mathrm{P}$, is well known (Tan and Melius, 1986 ), and activation of $\mathrm{B}[a] \mathrm{P}$ into DNA-binding species has been demonstrated in vivo (Kurelec et al., 1991; Shugart et al., 1987; Sikka et al., 1990; Varanasi et al., 1989). Metabolism of $\mathrm{B}[a] \mathrm{P}$ has been demonstrated in several mammalian and fish cultured cells; however, DNA adduct formation in fish has been observed only in cell lines and freshly isolated hepatocytes (Babich and Borenfreund, 1991; Jones et al., 1978; Steward et al., 1989). This study has now demonstrated the occurrence of DNA adducts in a primary culture of fish hepatocytes exposed to $\mathrm{B}[a] \mathrm{P}$.

The results presented here show that DNA adducts appear after a $12-\mathrm{hr}$ exposure to $\mathrm{B}[\mathrm{a}] \mathrm{P}$, but in 

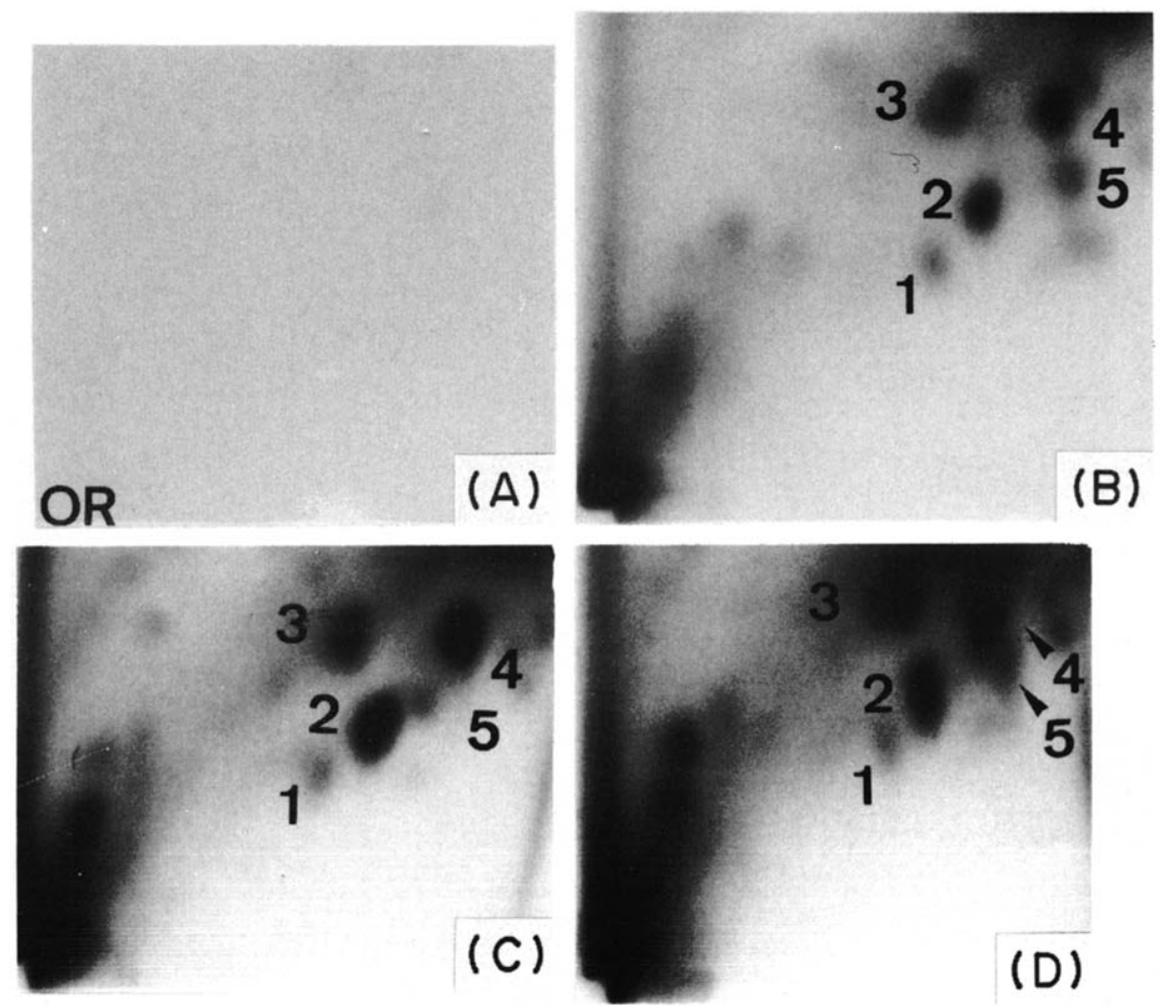

Plate 1. Autoradiograms of chromatograms of DNA adducts from control trout hepatocytes (A), trout hepatocytes (B) and trout liver treated with benzo $[a]$ pyrene $(\mathrm{B}[a] \mathrm{P})(\mathrm{C})$. Hepatocytes were treated with $1 \mu \mathrm{M}-\mathrm{B}[a] \mathrm{P}$ (final concentration); trout received ip $80 \mathrm{mg} \mathrm{B}[a] \mathrm{P} / \mathrm{kg}$ body weight and the liver was removed $48 \mathrm{hr}$ later. For hepatocytes and liver, $20 \mu \mathrm{g}$ DNA were analysed. For co-chromatography (D), 20- $\mu \mathrm{g}$ aliquots of each DNA sample were spotted on the same thin-layer chromatography plate. Autoradiography was at $-80^{\circ} \mathrm{C}$ for $24 \mathrm{hr}$ using an intensifying screen. $\mathrm{OR}=$ origin of chromatography at lower left-hand corner of the chromatogram. 

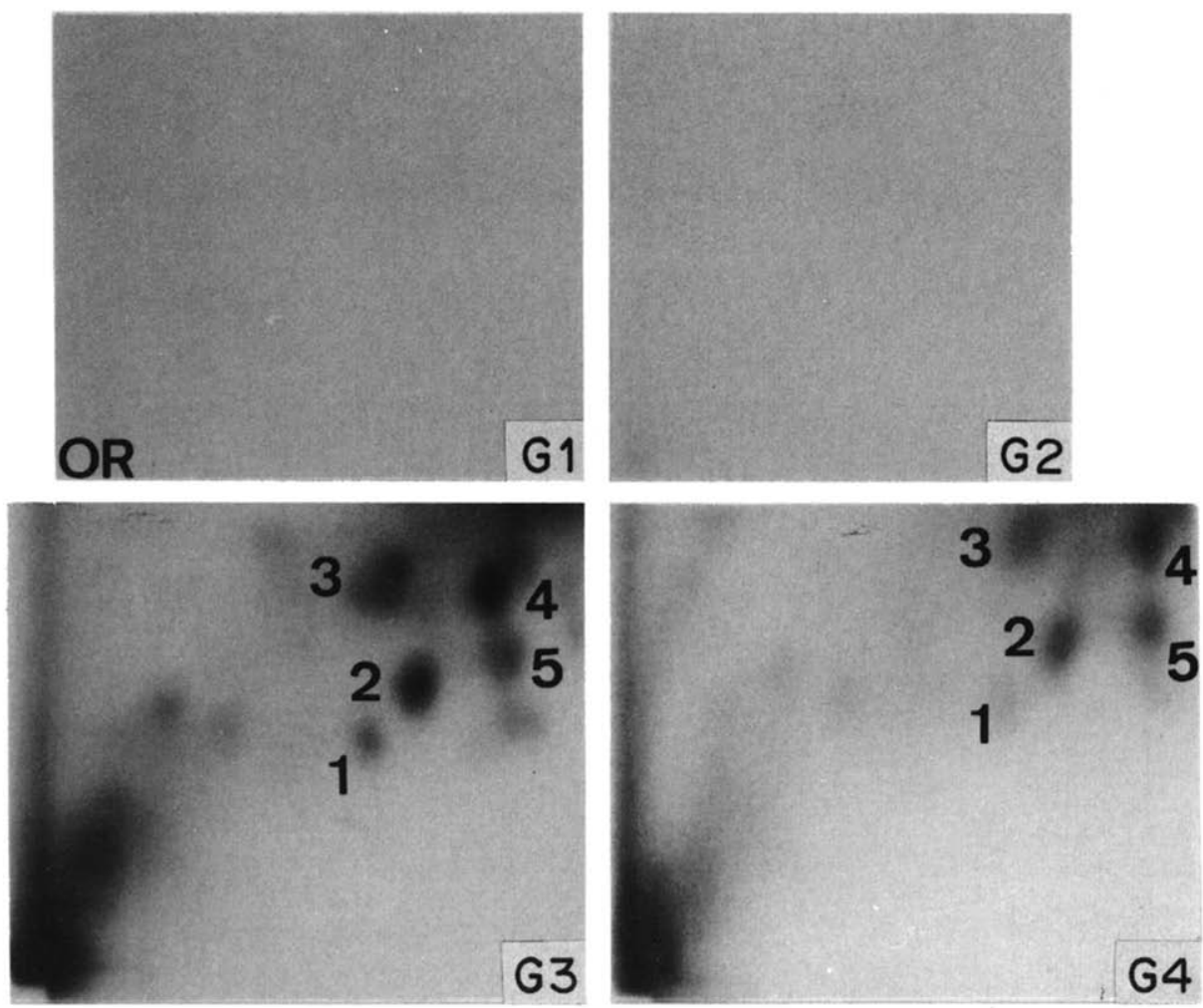

Plate 2. Autoradiograms of chromatograms of DNA adducts from control trout hepatocytes (G1), and those treated with $\beta \mathrm{NF}(\mathrm{G} 2), \mathrm{B}[a] \mathrm{P}$ (G3) or $\beta \mathrm{NF}$ plus $\mathrm{B}[a] \mathrm{P}(\mathrm{G} 4)$ (see Fig. 1 for protocol of treatment). $20-\mu \mathrm{g}$ aliquots of each DNA sample were analysed. Autoradiography was at $-80^{\circ} \mathrm{C}$ for $24 \mathrm{hr}$ using an intensifying screen. OR = origin of chromatography at lower left-hand corner of the chromatogram. 
Table 2. Level of the main DNA adducts detected in trout hepatocytes or trout liver following treatment with benzo[a]pyrene

\begin{tabular}{lccccc}
\hline & \multicolumn{6}{c}{ Level of DNA adducts (cpm)* } \\
\cline { 2 - 6 } Source of DNA & $1 \dagger$ & 2 & 3 & 4 & 5 \\
\hline $\begin{array}{l}\text { Hepatocytes } \\
\quad(20 \mu \mathrm{g} \text { DNA) }\end{array}$ & 117 & 323 & 465 & 436 & 243 \\
Liver & & & & & \\
$\quad(20 \mu$ g DNA) & 232 & 910 & 772 & 1333 & 139 \\
Co-chromatography & 361 & 1153 & 1278 & 1675 & 388 \\
& $(349) \ddagger$ & $(1233)$ & $(1236)$ & $(1769)$ & $(382)$ \\
\hline
\end{tabular}

*Level of DNA adducts is expressed as cpm/20 $\mathrm{gg}$ DNA from either hepatocytes or liver. Co-chromatography was carried out with $20 \mu \mathrm{g}$ DNA hydrolysate from both hepatocytes and liver.

†Adducts $1-5$ are those depicted in Plates 1 and 2.

tNumbers in parentheses indicate the total cpm expected for cochromatography, assuming additivity of the DNA adduct level in liver and hepatocytes.

Table 3. Level of DNA adducts detected from trout hepatocytes after a 24-hr treatment with benzo[a]pyrene with or without a $48-\mathrm{hr}$ pretreatment with $\beta$-naphthoflavone $(\beta \mathrm{NF})^{*}$

\begin{tabular}{|c|c|c|c|c|c|c|}
\hline \multirow[b]{2}{*}{ Pretreatment } & \multicolumn{6}{|c|}{ Level of different DNA adducts $\dagger$} \\
\hline & $1 \ddagger$ & 2 & 3 & 4 & 5 & $\begin{array}{c}\text { Total } \\
\text { adducts } \S\end{array}$ \\
\hline \multicolumn{7}{|l|}{ None } \\
\hline Sample 1 & 2.95 & 8.16 & 11.76 & 11.01 & 6.14 & 40.02 \\
\hline Sample 2 & 3.80 & 8.23 & 11.33 & 10.61 & 7.55 & 41.52 \\
\hline \multicolumn{7}{|l|}{$\beta \mathrm{NF}$} \\
\hline Sample 1 & 2.26 & 5.21 & 4.97 & 8.61 & 6.67 & 27.72 \\
\hline Sample 2 & nd & 7.58 & 9.89 & 9.39 & 5.19 & 32.05 \\
\hline Sample 3 & 2.88 & 6.00 & 10.89 & 10.32 & 6.80 & 36.89 \\
\hline
\end{tabular}

*See Fig. 1 for protocol of treatment. Each sample originates from three dishes.

tAdduct level is expressed as fmoles of adduct/mg DNA.

†Adducts $1-5$ are those depicted in Plates 1 and 2 .

$\$$ A significant difference (Mann-Whitney $U$-test) in total adduct level was shown between pretreated and non-pretreated hepatocytes.

\Total adducts for sample 2 in the $\beta$ NF-treated-group were calculated without taking into account adduct 1 , which was not determined (nd).

preliminary experiments adducts were detected after only $4 \mathrm{hr}$ (data not shown). DNA adducts could probably be detected even earlier, as suggested by Zaleski et al. (1991) who detected DNA adducts only $1 \mathrm{hr}$ after exposure to $40 \mu \mathrm{M}-\mathrm{B}[a] \mathrm{P}$ of freshly isolated hepatocytes from mirror carp. Unfortunately, these authors did not describe the effect of this concentration of $\mathrm{B}[a] \mathrm{P}$ on the activity of P4501A. As, in our study, EROD was not induced after $12 \mathrm{hr}$ of exposure, it seems likely that activation of $\mathrm{B}[a] \mathrm{P}$ by rainbow trout hepatocytes takes place before any significant increase in P4501 A protein content, which occurs after some delay caused by the synthesis of CYPIA mRNA, as recently shown by Pesonen et al. (1992).

A close similarity was shown between DNA adduct patterns generated in cultured hepatocytes and in vivo, suggesting that the metabolic activation of PAHs in primary culture of rainbow trout hepatocytes is representative of that in vivo. Studies have demonstrated the predominance of the adduct derived from $\mathrm{B}[a] \mathrm{P}$ 7,8-diol 9,10-epoxide (BPDE), in the liver, the isolated hepatocytes or the cell lines obtained from several fish species exposed to $\mathrm{B}[a] \mathrm{P}$ (Kurelec et al., 1991; Smolarek et al., 1987; Steward et al., 1989; Varanasi et al., 1989). However, it seems that the pattern of DNA adducts occurring after exposure to $\mathrm{B}[a] \mathrm{P}$ is species specific, since we and other authors have observed that the major adduct in trout detected after $\mathrm{B}[a] \mathrm{P}$ treatment in vivo (liver) and in the RTG-2 cell line (a fibroblast line) exposed to $\mathbf{B}[a] \mathbf{P}$, differed from the adduct derived from BPDE (Masfaraud et al., 1992; Smolarek et al., 1987).

The induction of EROD activity has been proposed as a biomarker of exposure to planar polycyclic hydrocarbons (PAHs, dioxins, furans and planar PCBs). Because of the involvement of P4501A in the activation of PAHs into their ultimate carcinogens, EROD might also be considered as a biomarker of the ability of a system to activate PAHs into DNAdamaging compounds (Stegeman and Lech, 1991). The primary culture of rainbow trout hepatocytes, in which EROD activity is inducible and DNA adducts are generated on exposure to $\mathrm{B}[a] \mathrm{P}$, enables the relationship between EROD activity and DNA adduct pattern and level to be examined.

The fact that the pattern of DNA adducts was the same as that observed in the absence of EROD induction (see experiment II) supports the assumption that $P 4501$ A was present in control hepatocytes, as recently shown by Pesonen et al. (1992) and that EROD induction did not result from the synthesis of new forms of $P-450$ involved in $\mathrm{B}[a] \mathrm{P}$ activation, but from reinforcement of the formation/stabilization of $P$-4501A present in the cells before treatment with $\beta N F$.

As implied by these results, the lack of association between EROD activity (P4501A level) and DNA adduct levels suggests a significant involvement of

Table 4. 7-Ethoxyresorufin $O$-deethylase (EROD) activity $\left(\mathrm{pmol} \cdot \mathrm{min}^{-1} \cdot \mathrm{mg}\right.$ protein $^{-1}$ ) in control hepatocytes or in hepatocytes treated with $\beta$-naphthoflavone $(\beta N F)$, benzo $[a]$ pyrene $(\mathrm{B}[a] \mathrm{P})$, or $\beta \mathrm{NF}+\mathrm{B}[a] \mathrm{P}$

\begin{tabular}{ccccc}
\hline & \multicolumn{4}{c}{ EROD activity after treatment } \\
\cline { 2 - 5 } Time in culture (hr) & Control & $\beta \mathrm{NF}$ & $\mathrm{B}[a] \mathrm{P}$ & $\beta \mathrm{NF}+\mathrm{B}[a] \mathrm{P}$ \\
\hline 72 & $77.3 \pm 8.9$ & $264.0 \pm 16.6^{*}$ & $-\S$ & $-\S$ \\
96 & $28.6 \pm 2.9$ & $72.8 \pm 8.8^{*}$ & $66.0 \pm 4.7^{*}$ & $121.8 \pm 15.9^{*} \ddagger$ \\
\hline
\end{tabular}

† See Fig. I for protocol of treatment. Each value corresponds to mean value \pm SD from three dishes.

$\ddagger$ At $96 \mathrm{hr}$, significantly different from $\beta \mathrm{NF}$ - and $\mathrm{B}[a] \mathrm{P}$-treated hepatocytes $(P<0.05)$.

$\S \mathrm{B}[a] \mathrm{P}$ added only after $72 \mathrm{hr}$ culture.

Significantly different from the control at 72 and $96 \mathrm{hr}\left({ }^{*} P<0.05\right)$ 
conjugating as well as DNA-repair enzymes in the regulation of DNA adduct formation and elimination, respectively, as discussed elsewhere (James, 1987; Klaunig, 1984; Zaleski et al., 1991). An increase in DNA adduct formation may require an induction threshold of P4501A that was not attained in our study (3.4-fold); thus, Monteith et al. (1990) observed that an 11-fold preinduction in AHH activity was correlated with no more than a 1.7 -fold increase in DNA-binding in a primary culture of human hepatocytes treated with radiolabelled $\mathrm{B}[a] \mathrm{P}$.

In conclusion, this study has demonstrated the formation of DNA adducts in a primary culture of rainbow trout hepatocytes exposed to $\mathrm{B}[a] \mathrm{P}$. The DNA-adduct pattern is very similar to that in the liver after treatment in vivo. Pre-exposure of hepatocytes to a $P 4501 \mathrm{~A}$ inducer failed to demonstrate a relationship between the level of DNA adduct and EROD activity, under the conditions of the present study. EROD activity is a good indicator of exposure to PAHs, but the conditions under which P4501A is the limiting factor for DNA adduct formation following PAH exposure remain to be elucidated. For this purpose, a primary culture of rainbow trout hepatocytes provides a suitable method in vitro.

Acknowledgements-We thank Professor G. Dirheimer (IBMC-Université Louis Pasteur) for valuable discussion and constant support. This work was supported in part by SRETIE (Ministère de l'Environnement, France) and Ministère de la Recherche et de la Technologie (France).

\section{REFERENCES}

Babich H. and Borenfreund E. (1991) Cytotoxicity and genotoxicity assays with cultured fish cells. Toxicology in Vitro 5, 91-100.

Conney A. H. (1982) Induction of microsomal enzymes by foreign chemicals and carcinogenesis by polycyclic aromatic hydrocarbons: G. H. A. Clowes memorial lecture. Cancer Research 42, 4875-4917.

Dunn B. P., Black J. J. and Maccubbin A. (1987) ${ }^{32}$ P-Postlabelling analysis of aromatic DNA adducts in fish from polluted areas. Cancer Research 47, 6543-6548.

Goksøyr A., Andersson T., Bulher D. R., Stegeman J. J., Williams D. E. and Förlin L. (1991) Immunochemical cross-reactivity of $\beta$-naphthoflavone-inducible cytochrome $P 450$ ( $P 450$ 1A) in liver microsomes from different fish species and rat. Fish Physiology and Biochemistry 9, 1-13.

Hartree E. F. (1972) Determination of protein: a modifcation of the Lowry method that gives a linear photometric response. Analytical Biochemistry 48, 422-427.

Henderson R. F., Bechtold W. E., Bond J. A. and Sun J. D. (1989) The use of biological markers in toxicology. CRC Critical Review in Toxicology 20, 65-82.

IARC (1987) IARC Monographs on the Evaluation of the Carcinogenic Risks to Humans. Suppl. 7. Overall Evaluations of Carcinogenicity: an Updating of IARC Monographs Volumes 1 to 42 . pp. 40-74. International Agency for Research on Cancer, Lyon.

Ioannides C. and Parke D. V. (1990) The cytochrome $P 4501$ gene family of microsomal hemoproteins and their role in the metabolic activation of chemicals. Drug Metabolism Reviews 22, 1-85.

James M. O. (1987) Conjugation of organic micropollutants in aquatic species. Environmental Health Perspectives 71, 97-108.

Jones C. A., Moore B. P., Cohen G. M., Fry J. R. and Bridges J. W. (1978) Studies on the metabolism and excretion of benzo(a)pyrene in isolated adult rat hepatocytes. Biochemical Pharmacology 27, 693-702.

Klaunig J. E. (1984) Establishment of fish hepatocytes cultures for use in in vitro carcinogenicity studies. National Cancer Institute Monograph 65, 163-173.

Kurelec B., Krca S., Garg A. and Gupta R. C. (1991) The potential of carp to bioactivate benzo(a)pyrene to metabolites that bind to DNA. Cancer Letters 27, 255-260.

Lu L. J. W., Disher R. M., Reddy M. V. and Randerath K. (1986) ${ }^{32}$ P-Postlabeling assay of transplacental DNA damage induced by the environmental carcinogens safrole, 4-aminobiphenyl, and benzo(a)pyrene. Cancer Research 46, 3046-3054.

Masfaraud J. F., Pfohl-Leszkowicz A., Malaveille C., Keith G. and Monod G. (1992) 7-Ethylresorufin $O$-deethylase activity and level of DNA-adducts in trout treated with benzo(a)pyrene. Marine Environmental Research. In press.

Miller E. C. and Miller J. A. (1981) Searches for ultimate chemical carcinogens and their reactions with cellular macromolecules. Cancer 47, 2327-2345.

Monod G., Devaux A. and Rivière J. L. (1987) Characterization of some monooxygenase activities and solubilization of hepatic cytochrome $P-450$ in two species of freshwater fish, the nase (Chondrostoma nasus) and the roach (Rutilus rutilus). Comparative Biochemistry and Physiology 88C, 83-89.

Monteith D. K., Ding D., Chen Y. T., Michalopoulos G. and Strom S. C. (1990) Induction of cytochrome $P_{1} 450$ mRNA and benzo(a)pyrene metabolism in primary human hepatocyte cultures with benzanthracene. Toxicology and Applied Pharmacology 105, 460-471.

Nemoto N., Sakurai J., Tazawa A. and Ishikawa T. (1990) Acquisition of aryl hydrocarbon hydroxylase inducibility by aromatic hydrocarbons in monolayer-cultured hepatocytes from nonresponsive mouse strains. Cancer Research 50, 3226-3230.

Okey A. B. (1990) Enzyme induction in the cytochrome $P-450$ system. Pharmacology and Therapeutics 45, 24I-298.

Perera F. (1987) The potential usefulness of biological markers in risk assessment. Environmental Health Perspectives 76, 141-145.

Pesonen M. and Andersson T. (1991) Characterization and induction of xenobiotic metabolizing enzyme activities in a primary culture of rainbow trout hepatocytes. Xenobiotica 21, 461-471.

Pesonen M., Goksøyr A. and Andersson T. (1992) Expression of P4501A1 in a primary culture of rainbow trout hepatocytes exposed to $\beta$-naphthoflavone or 2,3,7,8-tetrachlorodibenzo- $p$-dioxin. Archives of Biochemistry and Biophysics 292, 292-297.

Randerath K., Reddy M. V. and Gupta R. C. (1981) ${ }^{32}$ P-Labeling test for DNA damage. Proceedings of the National Academy of Sciences of the U.S.A. 78, 6126-6129.

Reddy M. V. and Randerath K. (1986) Nuclease $P_{1}$-mediated enhancement of sensitivity of ${ }^{32} \mathrm{P}$-postlabeling test for structurally diverse DNA adducts. Carcinogenesis 7, 1543-1551.

Seglen P. O. (1972) Preparation of rat liver cells. Experimental Cell Research 74, 450-454.

Shugart L., McCarthy V., Jimenez B. and Daniels J. (1987) Analysis of adduct formation in the bluegill sunfish (Lepomis macrochirus) between benzo(a)pyrene and DNA of the liver and hemoglobin of the erythrocyte. Aquatic Toxicology 9, 319-325.

Siegel S. (1956) Nonparametric Statistics for the Behavioral Sciences. p. 312. McGraw-Hill, New York. 
Sikka H. C., Rutkowski J. P., Kandaswami C., Kumar S., Earley K. and Gupta R. C. (1990) Formation and persistence of DNA adducts in the liver of brown bullheads exposed to benzo(a)pyrene. Cancer Letters 49, 81-87.

Smolarek T. A., Morgan S. L., Moyniham C. G., Lee H., Harvey R. G. and Baird W. M. (1987) Metabolism and DNA adduct formation of benzo(a)pyrene and 7,12dimethylbenz(a)anthracene in fish cell lines in culture. Carcinogenesis 8, 1501-1509.

Stegeman J. J. and Lech J. J. (1991) Cytochrome $P-450$ monooxygenase systems in aquatic species: carcinogen metabolism and biomarkers for carcinogen and pollutant exposure. Environmental Health Perspectives 90, 101-109.

Steward A. R., Zaleski J., Gupta R. and Sikka H. C. (1989) Comparative metabolism of benzo(a)pyrene and (-)benzo(a)pyrene-7,8-dihydrodiol by hepatocytes isolated from two species of bottom-dwelling fish. Marine Environmental Research 28, 137-140.
Tan B. and Melius P. (1986) Polynuclear aromatic hydrocarbon metabolism in fishes. Comparative Biochemistry and Physiology 83C, 217-224.

Vaillant C., Monod G., Valotaire Y. and Rivière J.-L. (1989) Measurement and induction of cytochrome $P$ 450 and monooxygenase activities in a primary culture of rainbow trout (Salmo gairdneri) hepatocytes. Comptes Rendus Académie des Sceances, Paris 308 (III), 83-88.

Varanasi U., Reichert W. L., Le Eberhart B. T. and Stein J. E. (1989) Formation and persistence of benzo(a)pyrenediolepoxide-DNA adducts in liver of English sole (Parophrys vetulus). Chemico-Biological Interactions 69, 203-216.

Zaleski J., Steward A. R. and Sikka H. C. (1991) Metabolism of benzo(a)pyrene and (-)-transbenzo(a)pyrene-7,8-dihydrodiol by freshly isolated hepatocytes from mirror carp. Carcinogenesis 12, $167-174$. 